\title{
Land Rights and Rural-Urban Migration in China
}

Maëlys De La Rupelle, Deng Quheng, Li Shi and Thomas Vendryes

\section{OpenEdition}

\section{Journals}

Electronic version

URL: http://journals.openedition.org/chinaperspectives/3633

DOI: 10.4000/chinaperspectives.3633

ISSN: 1996-4617

\section{Publisher}

Centre d'étude français sur la Chine contemporaine

\section{Printed version}

Date of publication: 4 April 2008

Number of pages: 25-35

ISSN: 2070-3449

\section{Electronic reference}

Maëlys De La Rupelle, Deng Quheng, Li Shi and Thomas Vendryes, «Land Rights and Rural-Urban Migration in China », China Perspectives [Online], 2008/2 | 2008, Online since 01 April 2011, connection on 28 October 2019. URL : http://journals.openedition.org/chinaperspectives/3633 ; DOI : 10.4000/ chinaperspectives.3633

(C) All rights reserved 


\title{
Land Rights and Rural-urban
}

Migration in China

\author{
MAËLYS DE LA RUPELLE, \\ DENG QUHENG, LI SHI \\ AND THOMAS VENDRYES
}

Collective ownership of agricultural land and the remains of the administrative management of rural economy have imposed considerable insecurity on the land use rights of Chinese farmers. This insecurity constrains the movement of rural people, who fear that migration will jeopardise what land use rights they do enjoy. In this paper we describe the idiosyncratic uncertainty of land use rights, and verify its influence on migration decisions, with a special focus on the duration of migration.

$\mathrm{B}$ eginning in 1978, the reform and opening policies first promoted by Deng Xiaoping led the People's Republic of China onto a path of rapid economic growth and sharp social change. These policies allowed the gradual dissemination of market processes, especially in terms of the allocation of production factors (labour, land, and capital). Even while markets remain far from complete and quite highly constrained, this partial liberalisation has given rise to a rapid pace of capital accumulation, and to a geographical and sectoral redistribution of the Chinese workforce. In particular, China has experienced increasing migration of labourers from rural agricultural areas to industrialised cities. Although the high mobility and marginalised living conditions of migrant rural workers make accurate estimates of their number difficult, existing studies have arrived at a commonly accepted estimate of the growth in this population from around 2 million in the mid-1980s to about 94 million in 2002. In other words, by the beginning of the twenty-first century, rural-urban migration affected as much as 12 percent of the total Chinese workforce, and nearly a fifth of the rural active population. ${ }^{(1)}$

The scope of this phenomenon gives it a crucial significance for the overall development of the People's Republic, as well as for the daily life of China's rural inhabitants, and it has naturally aroused much interest and debate in academic as well as political circles regarding its causes, evolution, and ramifications on economic development and social order. So far, on the micro side, the relevant economic literature has focused mainly on the specific characteristics of migrants, holding the classical Todarian view that differentials in labour revenues were the main motive for migration. ${ }^{(2)}$ Moreover, on the macro side, much of the political and social debate about Chinese internal migration seems to rely on the implicit assumption that this phenomenon is comparable to the exode rural that took place during Europe's industrialisation in the nineteenth century, and in most developing countries during the twentieth century. Rural-urban migration is thus seen, in a Lewisian manner, ${ }^{(3)}$ as the necessary corollary of capital accumulation, industrialisation, and urbanisation.

\section{The temporary nature of rural-urban migration}

However, this economic theoretical framework and historical baseline example does not seem to account for one of the most striking features of the Chinese migrant population, namely that it is a "floating population" (liudong renkou). Indeed, apart from numerical importance, another specific feature of rural-urban migration flows in China is their tem-

1. See for example the report of Huang Ping and Frank N. Pieke, "China Migration Country Study ", presented at the Regional Conference on Migration, Development, and Pro-poor Policy Choices in Asia, in Dhaka, Bangladesh, June 2003, p. 5 sq.

2. Michael P. Todaro, "A Model of Labour Migration and Urban Unemployment in Less Developed Countries," The American Economic Review, vol. 59, 1969, pp. 138148; John R. Harris and Michael P. Todaro, "Migration, Unemployment and Development: A Two-Sector Analysis," The American Economic Review, vol. 60, $\mathrm{n}^{\circ} 1$, 1970, pp. 126-142.

3. Arthur W. Lewis, "Economic Development with Unlimited Supply of Labour," The Manchester School of Economic and Social Studies, vol. 22, 1954, pp. 131-191. 
porality. It appears that most rural-urban migrants return to their native rural areas after some years spent working in informal urban labour markets, ${ }^{(4)}$ and that out-migration is merely a stage in the life-cycle of rural households or individuals. For example, in our data, about 75 percent of the rural migrants are under 35 years old, suggesting that rural-urban migration characterises the first stage of a rural individual's working life.

Moreover, even during this migratory stage of life, rural migrants keep moving back and forth between their home villages and the destination urban areas. ${ }^{(5)}$ For example, in our data sample, only 5 percent of the migrants did not return to their home village in 2002, and 60 percent of them spent less than 9 months outside their home county. The distribution of rural migrants according to the length of their out-migration in 2002, plotted in Figure 1, clearly reflects the temporal mobility of rural migrants and the diversity of their behaviours.

China's rural migrant population thus displays striking temporal characteristics: migrations appear temporary, that is, out-migration constitutes a transitory stage in a rural individual's life pattern, and is a phenomenon of repeated moves between home and destination areas rather than a more or less permanent settling. In fact, contemporary Chinese newspaper reports and officials speeches refer to the rural migrant population almost exclusively as the "floating population," explicitly stressing its high temporal mobility. The main objective of this paper is to shed some light on this temporary feature of rural migrant flows.

\section{Causes of temporary migration}

The temporary migration phenomenon, which is quite common in developing countries, is not a new issue in economics, and has already given birth to a wide literature. From an economic standpoint, the first general explanation given to account for temporary migration is changes in the revenue differentials between origin and destination areas due, for example, to agricultural seasonality. John Knight and Lina Song, ${ }^{(6)}$ as well as Claude Aubert and Li Xiande, ${ }^{(7)}$ convincingly apply this reasoning to the case of China. Secondly, temporary migration can be caused by exogenous impacts on the legal and/or professional situations of migrants. Oded Galor and Oded Stark ${ }^{(8)}$ observed that the instability of informal labour markets and the fragility of the administrative situation of many undocumented migrants can force some of them to return home. This analysis is quite relevant in the case of Chinese rural migrants, whose urban residen-
Figure 1. Distribution of rural migrants according to the length of their migration in 2002

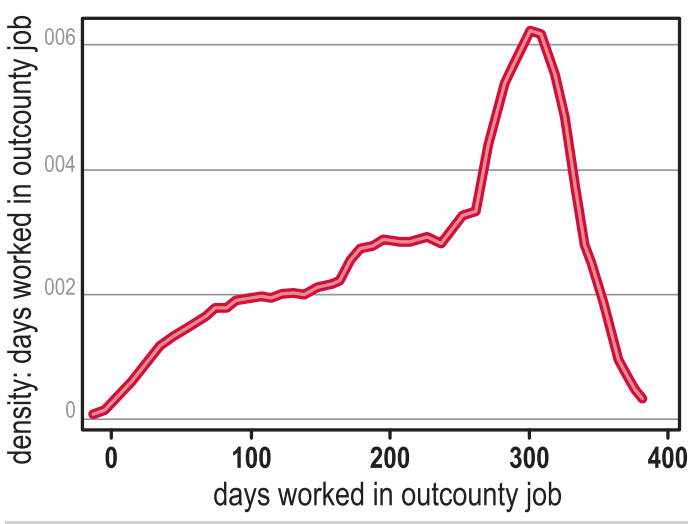

Authors' computation from CHIP, CASS, 2002

tial rights are limited and easily challenged in an institutional context of controlled population movement. Thirdly, repeated returns to the home area could be explained by the psychological cost of migration, and especially family ties. As time passes, the cost of being far from home and family increases. Technically, in this case, economic models normally assume that consumption at home brings a higher utility than consumption at the migrant's destination (as in the work of Slobodan Djajic and Ross Milbourne), ${ }^{(9)}$ or impute financial "explicit costs" and "implicit psychic costs" to migration, as in Zhao Yaohui's ${ }^{(10)}$ terminology. But in this case, the back-pulling force is assumed rather than explained. Fourthly, the high mobility of migrants could be due to a process of geographical searching, in which migrants lack information on destination labour markets and thus look for the best destination through circular migration, as pointed

4. See Rachel Murphy, How Migrant Labour is Changing Rural China, Cambridge, Cambridge University Press, 2002, p. 124 sq.

5. Denise Hare, "'Push' versus 'Pull' Factors in Migration Outflows and Returns: Determinants of Migration Status and Spell Duration Among China's Rural Population," in Sarah Cook and Margaret Maurer-Fauzio (eds.), The Workers' State Meets the Market: Labour in China's Transition, London, Routledge, 1999, pp. 45-72.

6. John Knight and Lina Song, "Chinese Peasant Choices: Farming, Rural Industry or Migration," Oxford Development Studies, vol. 31, n² 2, 2003, pp. 123-148.

7. Claude Aubert and Li Xiande, "Sous-emploi agricole et migrations rurales en Chine, faits et chiffres," Perspectives Chinoises, $n^{\circ}$ 70, April 2002, pp. 49-62.

8. Oded Galor and Oded Stark, "Migrant Savings, the Probability of Return Migration and Migrant's Performance," International Economic Review, vol. 31, n², 1990, pp. 463467.

9. Slobodan Djajic and Ross Milbourne, "A General Equilibrium Model of Guest Worker Migration: The Source-Country Perspective," Journal of International Economics, vol. 25, 1988, n 3-4, pp. 335-351.

10. Zhao Yaohui, "Labour Migration and Earning Differences: The Case of Rural China," Economic Development and Cultural Change, vol. 47, n 4, 1999, pp. 767-782. 
A Chinese farmer works on land situated close to Beijing. (C) AFP out in the pioneering work of Gautam Bhattacharya. ${ }^{(I)}$ Fifthly and finally, temporary migrations can express the behaviour of households willing to spread risk among sectors and localities, as conceptualised by Oded Stark. ${ }^{(12)}$ In this framework, people leave for cities in order to cope with volatile agricultural income, making migration an insurance device.

\section{Specific features of the chinese case}

All these explanations are likely to play a role in understanding Chinese internal migration temporality. Furthermore, two specific characteristics of China labour and land markets clearly affect the migration decisions of Chinese rural households.

Firstly, from the 1950s onward, Chinese people have been enrolled in a "household registration system" or hukou framework. In the 1960s and 1970s, Chinese individuals' places of residence and work were strictly defined through this institution. ${ }^{(13)}$ Although controls on mobility have been relaxed during the last two decades, the very existence of this hukou system still constrains the movement of rural people, mainly because, as Dorothy J. Solinger ${ }^{(14)}$ succinctly states, "civil/social rights and prerogatives, such as the right to subsistence, education, dwelling, employment, and medical care are denied to migrants in the cities." They thus remain second-class citizens in urban areas, and though the hukou rural/urban divide has become clearly less hermetic since the beginning of the reform era, it still firmly hinders the permanent settlement of rural migrants in cities.

Secondly, the decollectivisation of rural economy and agricultural production, initiated at the end of the 1970s, has never been completed. To be more specific, in 1978, the rural People's Communes were dismantled, and more freedom was granted to farming households. However, property rights have remained in the hands of village collective authorities, and rural households have only been conceded land use rights. These land use rights were to be allocated through a well-defined contractual framework, the "Household Responsibility System," but in fact, contracts, and especially contract lengths, have not been fulfilled by collective authorities, who have maintained the habit of periodically reallocating collective land among their fellow villagers. This situation creates a manifest uncertainty for rural households about the durability of their land tenure. Moreover, this uncertainty is quite variable from one locality to another according to village-level collective management of land, and from one plot to another, according to the varying contrac-

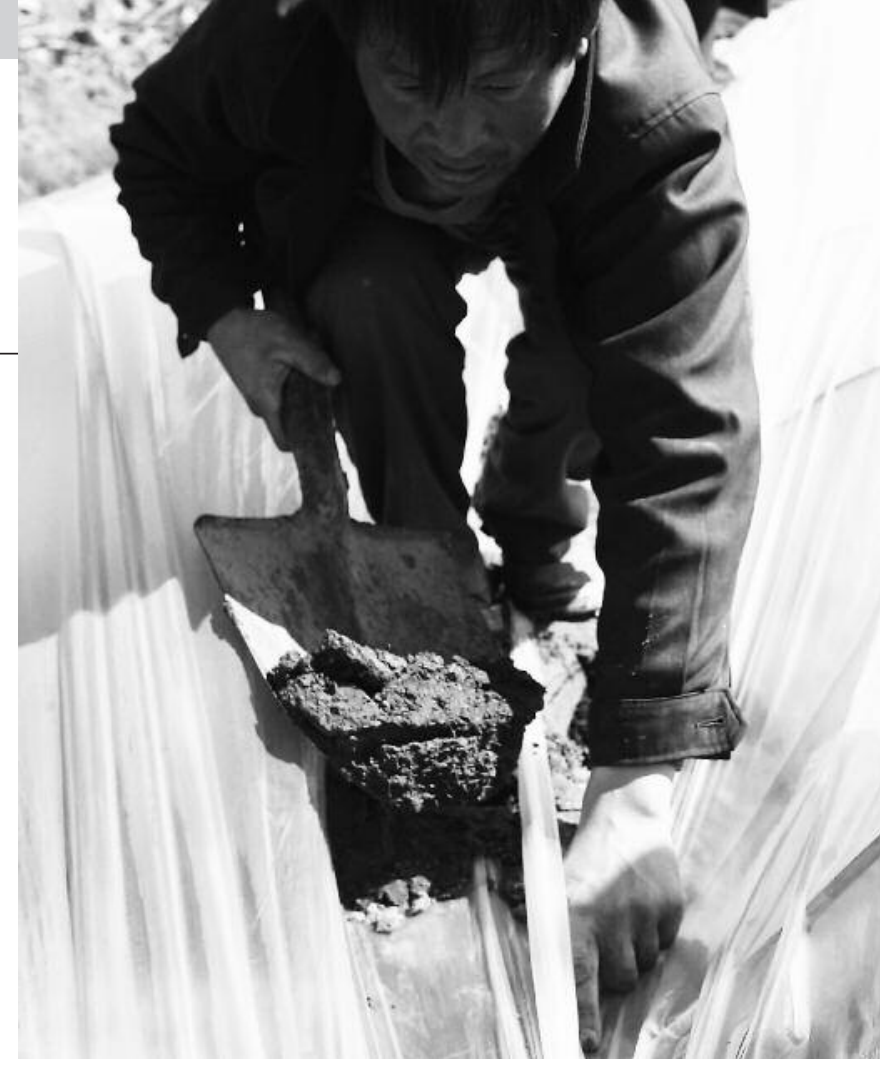

tual status of land parcels. ${ }^{(15)}$ In this paper we will focus on this peculiar aspect of rural China institutions and the consequent uncertainty of land rights, to shed some light on the temporary aspect of Chinese rural migration.

The problem of land rights uncertainty in developing countries and emerging economies has already given birth to a wide literature focusing on the link between land rights and rural household behaviour, especially productive investment. ${ }^{(16)}$ For example, in a reference work ${ }^{(17)}$ on the case of China, Hanan G. Jacoby, Li Guo, and Scott Rozelle study

11. Gautam Bhattacharya, "Migration under Uncertainty about Quality of Locations," Journal of Economic Dynamics and Control, vol. 14, n³-4, 1990, pp. 721-739.

12. Oded Stark and David Levhari, "On Migration and Risks in LDCs," Economic Development and Cultural Change, vol. 31, n 1, 1982, pp. 191-196; Oded Stark and David E. Bloom, "The New Economics of Labour Migration," The American Review, vol. 75, n², 1985, Papers and Proceedings of the Ninety-Seventh Annual Meeting of the American Economic Association.

13. A comprehensive depiction of the hukou system and of its evolution can be found in Cheng Tiejun and Mark Selden, "The Origins and Social Consequences of China's Hukou System," The China Quarterly, n 139, 1994, pp. 644-688. Evolutions of this system in the 1980s and 1990s are related in Kam Wing Cham and Li Zhang, "The Hukou System and Rural-Urban Migration in China Processes and Changes," The China Quarterly, ${ }^{\circ}$ 160, 1999, pp. 818-855.

14. Dorothy J. Solinger, "Citizenship Issues in China's Internal Migration: Comparisons with Germany and Japan," Political Science Quarterly, vol. 114, n 3, 1999, p. 469.

15. Charles C. Krusekopf, "Diversity in Land Tenure Arrangements under the Household Responsibility System in China," China Economic Review, vol. 13, n² 2, 2002, pp. 297-312; Loren Brandt, Jikun Huang, Guo Li, and Scott Rozelle, "Land Rights in China, Facts, Fictions and Issues," The China Journal, ${ }^{\circ}$ 47, 2002, pp. 67-97.

16. The question of land rights tenure insecurity is well documented for Ethiopia, Ghana, and Peru in the following papers: Daniel Ayalew, Stefan Dercon, and Madhur Ghautam, "Property Rights in a Very Poor Country: Tenure Insecurity and Investment in Ethiopia," World Bank Policy Research Working Paper No. 4363, 2007; Markus Goldstein and Christopher Udry, "The Profits of Power: Land Rights and Agricultural Investment in Ghana," Yale University Economic Growth Centre Discussion Paper No. 929, 2005; and Erica Field, "Entitled to work: Urban Property Rights and Labour Supply in Peru," Quarterly Journal of Economics, 2007.

17. Hanan G. Jacoby, Li Guo, and Scott Rozelle, "Hazards of Expropriation: Tenure Insecurity and Investment in Rural China," The American Economic Review, vol. 92, n 5, 2002, pp. 1420-1447. 
the relationship between the insecurity of land use rights (based on contractual classification and land collective management policies) and the use of organic fertilizer, which can be considered an investment because of its middle-term improvement of soil quality. The study shows that, as expected, a household with less security in relation to a given plot will use less fertilizer. As for the impact of land rights insecurity on migration, past studies ${ }^{(18)}$ have already tried to establish, theoretically as well as empirically, that in the case of China, the remnant of collective land management acts as a hindrance to migration. Indeed, a rural individual migrating out of his village and thus neglecting his land is likely to see his land endowment at least partially seized by collective authorities for reallocation to fellow villagers who remain actively involved in agriculture. In such a context, leaving one's own land for the purpose of migration creates a risk of losing it to more consistently present individuals during the next reallocation.

The objective of our study is thus to establish a link between land rights uncertainty and migration decisions in China. More specifically, we attempt to show that Chinese rural individuals are exposed to an idiosyncratic risk of being deprived of their land use rights, and that this risk or uncertainty regarding future land endowments acts as a constraint on their migration decisions, and especially on the length of their out-migration.

The first assumption we thus have to ground is that rural individuals face an idiosyncratic risk of losing their land use rights.

\section{Land rights insecurity in China}

In 1978, with the implementation of the Household Responsibility System, People's Commune rural agricultural land was divided into various plots, which were then granted to rural households on a contractual basis. This framework has remained more or less unchanged up to the present. The underlying idea behind this institutional scheme was to give rural households relative freedom in their productive choices, and to grant them secure land use rights as a means of promoting individual investment. However, as mentioned earlier, land contracts have been only partially fulfilled by village collective authorities, who have not completely given up their control over agricultural land allocation. Administrative redistribution, in particular, continues as before. As a result, rural households enjoy less secure land rights than envisioned by the central authorities under the official framework of the Household Responsibility System. In this context, security of rights over a specific plot of land depends on three factors: the village authorities' land management, the contractual status of the plot, and the characteristics of the plot rights owner.

Indeed, even if the Household Responsibility System scheme was designed to be applied uniformly throughout mainland China, its actual implementation by village authorities takes very differing forms. Despite the existence of land contracts, administrative redistribution persists, with frequency and criteria differing considerably from one village to the next, as documented by James Kai-sing Kung ${ }^{(19)}$ and Liu Shouying, Michael R. Carter, and Yang Yao. ${ }^{(20)}$ The first dimension of variation in land rights uncertainty is thus geographical, as land rights security varies from village to village according to local political choices regarding agricultural land management and the actual implementation of the Household Responsibility System.

In terms of the second dimension of variation, different kinds of land contracts are defined under the framework of the Household Responsibility System, and Chinese rural households use agricultural land under various land tenure types and rights. Five major tenure types are officially sanctioned by the national government: ${ }^{(21)}$ private plot (ziliu di), grain ration land (kouliang tian), contract land (chengbao tian), responsibility land (zeren tian), and reclaimed land (kaihuang di). Generally speaking, the property rights on all agricultural land remain in the hands of the village collective authorities, and there is no private land ownership in any real sense. Moreover, each tenure type encompasses a different set of rights and obligations for rural households, and guarantees a different level of security. In particular, rural households have almost complete control, except for the right of title transfer, over private plots and grain ration lands, generally without obligation. Responsibility land, contract land, and reclaimed land, on the other hand, impose various obligations, such as the delivery of a mandatory quota of grain to the state at below-market prices, and can

18. Dennis Tao Yang, "China's Land Arrangements and rural Labour Mobility," China Economic Review, vol. 8, n² 2, 1997, pp. 101-115; Bryan Lohmar, "Land Tenure Insecurity and Labour Allocation in Rural China," paper presented at the American Agricultural Economics Association 1999 Annual Meeting, August 8-11, 1999, Nashville, TN; and Shi Xiaoxia, "The Impact of Insecure Land Use Rights on Labour Migration: The Case of China," CCER EConomic Papers, vol. 4, n²2, 2004, pp. 1-24

19. James Kai-sing Kung, "Common Property Rights and Land Reallocations in Rural China: Evidence from a Village Survey," World Development, vol. 28, n 4, 2000, pp. 701-719.

20. Liu Shouying, Michael R. Carter, and Yao Yang, "Dimensions and Diversity of Property Rights in Rural China: Dilemmas on the Road to Further Reform," World Development, vol. $26, n^{\circ} 10,1998$, pp. 1789-1806.

21. For a precise and comprehensive account of Chinese different tenure types, see Loren Brandt, Jikun Huang, Guo Li, and Scott Rozelle, "Land Rights in China, Facts, Fictions and Issues," art. cit. 
(CASS) in 2003. Carried out during the 2003 Spring Festival, it inquired into the situation of rural households during the preceding year. This survey has four main advantages: First, the set of questions was quite comprehensive, and covers a wide range of aspects of rural life. Second, the survey relies on a very large sampling: 37,969 individuals from 9,200 households distributed across 22 provinces, ${ }^{(22)}$ drawn up from NBS data in order to be representative of China's population as a whole. Third, it was conducted during the Spring Festival, a time of traditional familial gathering during which many migrants had returned their hometowns. Fourth and last, but not least, this individual and householdlevel survey is complemented by extensive data on villagelevel characteristics. These four factors make this survey highly relevant to the study of Chinese internal migration.

\section{Is the survey sample representative?}

We felt it necessary, nevertheless, to verify that the survey sample is representative of China's overall population; if not, the external validity of our analysis would be jeopardised, and we would not be able to draw conclusions for China as whole. Therefore, we compared simple descriptions of the population characteristics inferred from the survey data with those given for the various provinces in the National Bureau of Statistics of China (NBS) Statistical Yearbooks. It appears that in terms of age structure, gender ratio, and household composition, the survey results are very similar to the national statistics. It is interesting to note, however, that when we focus on working people, the survey results for some provinces diverge from the NBS estimates. Notably, the share of working people in the overall population was higher in the survey data than in the Statistical Yearbooks for some provinces such as Anhui, Jiangxi, Guangxi, Guangdong, Jiangsu, and Sichuan, while it appears that these provinces also have the highest proportion of people working outside their home county for at least six months out of a year. How can we reconcile the survey with the NBS data?

In fact, it is quite likely that the survey, carried out during a traditional time of familial gathering, interviewed workers who would not appear in the national data, because they are simply not at home most of the year. It is thus easy to understand why the provinces that are the main sources of Chinese internal migration have a higher worker population in the survey data than in the national statistics. All in all, we can assume that the survey population was well sampled and can be considered representative of the Chinese population as a whole. Our assumption in this regard is further strengthened by our data on migrant population characteristics.

\section{Who are the migrants?}

We must first define migration and delineate our survey migrant population. Migration is usually defined in relation to two criteria: place of work, and length of work. The National Bureau of Statistics defines a migrant as an individual who has left his place of residence registration in order to work for at least six months. For the purpose of this study, which is particularly concerned with the temporal dimension of migration, we define as a migrant any individual who says that he worked out of his usual place of residence during the past year, whatever the length of his out migration. The only restriction we put on this definition is geographical, namely that the place of work must be not only outside of the individual's home village and township, but also outside of the individual's home county. The imposition of this criterion may appear arbitrary, given that even individuals working within their county but out their township can live far from their household, or sleep in dorms at their workplace and not visit their family for months. However, Chinese townships can be quite small, and there may be many workers commuting to work outside their home township but within their home county. As for counties, the mean area is larger, and commuting should be a less viable option. In 2002, there were 44,850 township-level divisions, and 2,860 county-level divisions. Given that China as a whole measures 9.33 million square kilometres, townships average a bit more than 200 square kilometres in area, while counties are in average more than 3,260 square kilometres. In rural areas, the average area is slightly larger, but the difference between these two hierarchical levels remains huge. It follows from these geographical considerations that workers who stay within their home county can quite easily be commuters, and as such are not included in our definition of migrant workers.

To confirm the relevance of our definition of migrant workers, we first examine the plausibility of the resulting figures for the migrant population. According to the survey results, 15.4 percent of rural workers spent some time working outside their home county in 2002. That is, 9 percent of the rural population are migrant workers. If we assume a representative sampling, this means that 9 percent of the 853.24 million rural residents of the sampled provinces are migrants, and that 82.6 million individuals left their rural households

22. The provinces sampled include: (listed from East to West, and from North to South) Jilin, Liaoning, Beijing, Hebei, Shandong, Jiangsu, Zhejiang, Guangdong, Shanxi, Henan, Anhui, Hubei, Jiangxi, Hunan, Shaanxi, Chongqing, Guizhou, Guangxi, Xinjiang, Gansu, Sichuan, Yunnan. 
to work outside their county in 2002. If we further suppose that the 22 provinces in our sample are representative of China's national situation, it would mean that 93 million rural individuals migrated in 2002. ${ }^{(23)}$ In fact, this corresponds remarkably well with previous estimates of the size of the floating population, and reaffirms our confidence in the representative nature of the survey sample.

\section{Migrant characteristics}

Before focusing on the impact of land rights on migration decisions, we need a clear idea of who the migrants are. Compared with other rural workers, migrants tend to be younger and better educated.

Table 1. Age and education among migrants and non migrants

\begin{tabular}{|c|c|c|c|c|}
\hline & $\begin{array}{r}\text { Mi } \\
\text { Mean }\end{array}$ & $\begin{array}{l}\text { grants } \\
\text { Standard } \\
\text { Error }\end{array}$ & $\begin{array}{l}\text { Non } \\
\text { Mean }\end{array}$ & $\begin{array}{l}\text { Migrants } \\
\text { Standard } \\
\text { Error }\end{array}$ \\
\hline Age & 28.7 & 9.9 & 40.2 & 12.9 \\
\hline $\begin{array}{l}\text { Years of } \\
\text { education }\end{array}$ & 8.7 & 2.5 & 7.4 & 3.4 \\
\hline
\end{tabular}

Source: Authors' computation from CHIP, CASS, 2002

They are less likely to be married, and are less often the head of their household. Being married decreases the probability of migrating by 37 percent. Men make up a larger share than in the population as a whole: the probability of migrating is 50 percent higher for men than for women.

Table 2. Descriptive statistics

\begin{tabular}{|c|c|c|c|}
\hline Among : & Migrants & $\begin{array}{c}\text { Non } \\
\text { Migrants }\end{array}$ & $\begin{array}{c}\text { Total } \\
\text { Population }\end{array}$ \\
\hline \multicolumn{4}{|c|}{ Percentage of people who are: } \\
\hline Men & 66.6 & 52.8 & 54.8 \\
\hline Married & 48.5 & 82.5 & 77.6 \\
\hline $\begin{array}{l}\text { Household's } \\
\text { head }\end{array}$ & 23.9 & 38.6 & 36.5 \\
\hline
\end{tabular}

Source: Authors' computation from CHIP, CASS, 2002
Among households with migrant members, 72 percent have only one member migrating, 22 percent have two members working outside the county, and 6 percent have three or more members working as migrants.

Regarding the place of work, the majority of migrant workers are long-distance migrants, working outside their province of origin.

Table 3. Place of work of active people

\begin{tabular}{l|r}
\hline Place of work & $\begin{array}{r}\text { Percent } \\
\text { of } \\
\text { active } \\
\text { people }\end{array}$ \\
\hline Within village & 16.5 \\
Outside village, within township & 10.3 \\
Outside township, within county & 5.6 \\
Outside county, within province & 6.8 \\
Outside province & 8.1 \\
Agricultural work- Place of work missing & 52.7 \\
Total & 100 \\
\hline Source: Authors' computation from CHIP, CASS, 2002 & \\
\hline
\end{tabular}

These descriptive statistics are consistent with previous studies on the migrant population. We can now investigate the core of our research on migration decisions, and assess the impact of land rights insecurity in terms of village propensity to reallocate, social resources, and land tenure type.

\section{Migrants shorten out-migration when a reallocation is likely to occur}

Our survey found that village authorities have different attitudes toward administrative land reallocations. Some have never reallocated land since the Household Responsibility System was implemented at the end of the 1970s, while others have carried out periodic reallocations at a relatively high frequency. Moreover, decisions regarding reallocation can be taken at either an administrative or natural village level, and their extent can vary greatly from partial reallocation (tiliu ji-

23. Based on a rural population of $935,025,000$ people. All the figures are from the National Bureau of Statistics of China (NBS), Zhongguo tongii nianjian, China Statistical Yearbook, Chapter 12-3, "Basic conditions of grass roots units," China Statistics Press, Beijing, 2003. 
dong tian) to village-wide readjustment (tiaozheng). In our sample, more than two-thirds of villages carry out reallocations at the natural village level. Interestingly enough, when reallocations are conducted at a higher level and concern the administrative village level, they appear to be much more frequent.

In 1998, a Land Management Law sought to strengthen land tenure security and reduce the frequency of land readjustments ${ }^{(24)}$ by requiring the agreement of two thirds of the "villager representatives" (cunmin daibiao) and the approval of the township government responsible for agriculture. Even so, 40 percent of the villages surveyed in our sample have conducted at least one village-wide reallocation since 1998, and in some of them reallocations have occurred nearly every year.

Table 4. Large-scale land adjustment

\begin{tabular}{l|r}
\hline \hline $\begin{array}{l}\text { Village-wide adjustment(s) } \\
\text { since 1998 }\end{array}$ & $\begin{array}{r}\text { Percent of } \\
\text { villages }\end{array}$ \\
\hline No adjustment & 60 \\
One adjustment & 27 \\
Two adjustments & 7.3 \\
Three and more & 5.7 \\
Total & 100 \\
\hline
\end{tabular}

Source: Authors' computation from CHIP, CASS, 2002

As a measure of village-level risk, we also considered partial reallocations, which are more likely to occur. A labourer faced a higher uncertainty over her land rights in 2002 if her village conducted a partial reallocation. In 2002, 23 percent of villages conducted such a reallocation.

This does not provide the risk of reallocation per se, but all places where reallocation occurred were places where there was a risk of reallocation in 2002. This is an ex post measure of risk, since not all places facing a risk of reallocation actually experienced reallocation. But if such a risk has an impact on migration decisions, then we should see people taking this risk into account in places where a reallocation occurred.

If we plot the density of rural migrants according to the number of days they spent working outside their home county under two different situations, whether a reallocation occurred or not in 2002, we distinguish two very different temporality patterns. The following graph clearly indicates that the mean duration of migration was much lower in places where a reallocation occurred.
Figure 2. Migration duration and reallocation

Days worked outside county whether reallocation occurred in 2002 or not

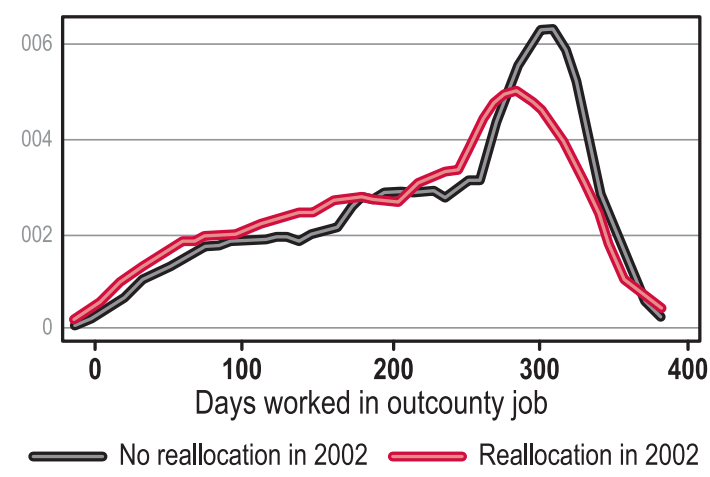

Source: Authors' computation from CHIP, CASS, 2002

The red curve, representing the density of migration durations when people faced reallocation, is shifted to the left compared with the black curve, which represents the density when no reallocation occurred. This clearly indicates that migrant workers shorten their migration when a reallocation takes place. The main peak indicates the highest frequency, the mode of migration length, in the sample population, which came out at around 280 days for migrant workers facing a reallocation in 2002, against 330 days where no reallocation occurred.

These results are consistent with our first hypothesis, namely that migrant decisions are affected by land rights uncertainty.

\section{Women's rights are less secure}

All individuals do not face an equal level of risk when a reallocation occurs, with the result that gender determines different migration patterns. Gender is associated with quite complex issues regarding land and migration.

Migrant women are very often at a disadvantage during land reallocation. ${ }^{(25)}$ Legally, women and men should have similar rights regarding land; article 48 of China's Constitution, article 28 and 30 of the Law on Protecting Women's Rights and Interests of the PRC, the Marriage Law of 2001 (in

24. Roy Prosterman, Tim Hanstad, Brian Schwarzwalder, Li Ping, "Rural Land Reform in China and the 1998 Land Management Law," Seattle, WA, Rural Development Institute 1998, paper available at the following address: http://www.rdiland.org/PDF/PDF Reports/RDI_098.pdf.

25. See for instance; Judd Ellen R, "No Change for Thirty Years: The Renewed Question of Women's Land Rights in Rural China," Development and Change, vol. 38, $n^{\circ} 4$, pp. 689-710, 2007; Jennifer Duncan and Li Ping, Women and Land Tenure in China:A Study of Women's Land Rights in Dongfang County, Hainan Province, Seattle, Wash., Rural Development Institute, 2001 
particular article 39), and article 10 of the Inheritance Law of 1985 all assert that women enjoy equal land rights. ${ }^{(26)}$ In some villages, however, women are entitled to less land than men under explicit reallocation rules.

The situation is further complicated by the tradition calling for a married woman to move to her husband's village. ${ }^{(27)}$ Virilocal marriage, that is, marriage where the woman leaves her natal village to join her husband's village, has been almost universal throughout Chinese history, and applied to an estimated 92 to 98 percent of rural Chinese marriages at the end of the 1990s. ${ }^{(28)}$ Since only men can inherit land, women often have to wait for the next reallocation to occur. Two situations can arise: If a woman's place of residence has not been transferred to her husband's village, her land in her village of origin is threatened under reallocation, even though it should remain in her hands. If her hukou has been transferred to their husband's village, on the other hand, she often has to wait for the next land adjustment, and even then she must strongly defend her interests. Last but not least, single working women come under great pressure, since their fellow villagers expect them to leave their village in the near future, and they are at a disadvantage if a reallocation occurs. ${ }^{(29)}$ For this reason, they may have a stronger incentive to be in their village during a reallocation.

The two following graphs represent reallocation's impact on men and women. We know that once married, men and women face quite different situations, even with respect to the law. (It is only since 2003 that the New Rural Law has stressed married women's rights. ${ }^{\left({ }^{30}\right)}$ ) Furthermore, once children are born, family life imposes different roles on women and men. In order to focus on the specific issue of gender rather than marriage, therefore, we focus on the situation for single workers.

The impact is indicated by the gap between the black and red curves, which suggests that the impact of reallocation is greater for women. Gender thus turns out to be a contributing factor in the idiosyncratic insecurity of rural individuals' land rights.

We will complete our analysis of the links between land rights and migration decisions with the final dimension of land use rights insecurity, namely plot-level.

\section{Grain ration land provides a measure of security}

In the 1980s, Pingdu, a county-level city in Shandong Province, implemented an original system of land management in order to meet the demands of efficiency without sacrificing the objectives of equity. ${ }^{\left({ }^{(1)}\right)}$ In 1986, Pingdu established two types of land tenure: one to fulfil basic consump-
Figure 3. Migration duration and gender

Days worked outside county for single women

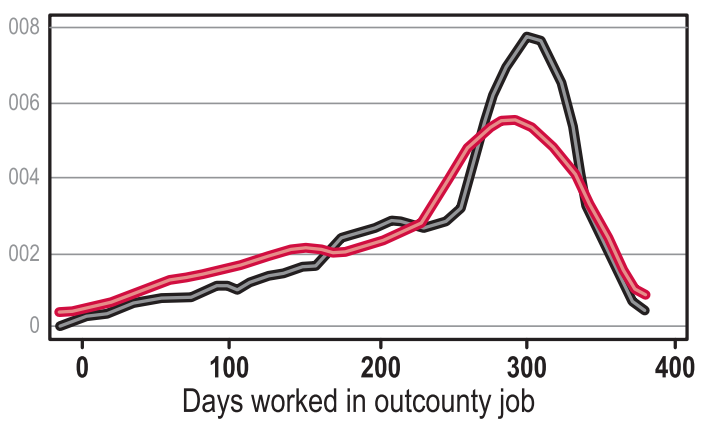

Days worked outside county for single men

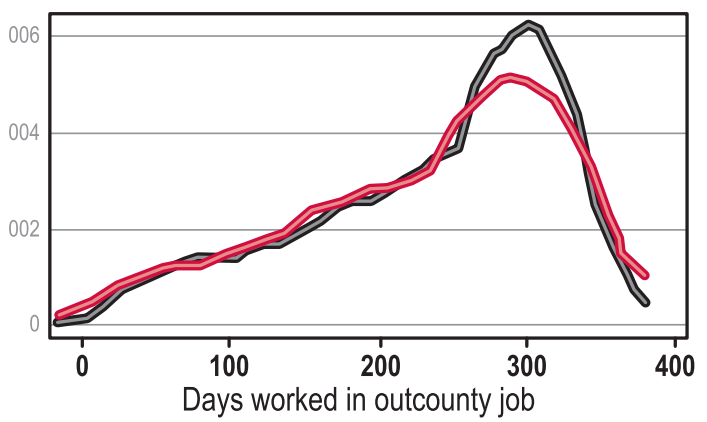

No reallocation in 2002

Reallocation in 2002

Source: Authors' computation from CHIP, CASS, 2002

tion needs, and the other aimed at increasing productivity. The former type was referred to as grain ration land. A similar "two-land system" quickly spread throughout rural

26. As stressed in Fu Chen, Wang Liming, and John Davis, "Land Reform in Rural China Since the Mid-1980s," Food and Agriculture Organization of the United Nations, Sustainable Development Department, 1999, paper available at the following address: $\mathrm{ftp} / / / \mathrm{ftp}$.fao.org/sd/sda/sdaa/LR98_2/art-9.pdf.

27. Burton Pasternak, "On the Cause and Demographic Consequences of Uxorilocal Marriage in China," in S.B. Hanley S. B. and A.P. Wolf (eds.), Family and Population in East Asian History, Stanford University Press, Stanford, CA, 1985.

28. Jin Xiaoyi, Li Shuzhuo, and Marcus W. Feldman, "Marriage Form and Fertility in Rural China," Morrison Institute for Population and Resource Studies Working Paper 101, Stanford University, Stanford, CA, 2004.

29. As pointed out in Denise Hare, Yang Li, and Daniel Englander, "Land Management in Rural China and Its Gender Implications," Feminist Economics, vol. 13, n 3-4, 2007, pp. 35-61.

30. An English translation of the Law of the People's Republic of China on Land Contract in Rural Areas, which went into effect in 2003, is available at the following address: http://english.gov.cn/laws/2005-10/09/content_75300.htm.

31. Fu Chen, Wang Liming, and John Davis, art. cit 
Figure 4. Migration duration and tenure types

Days worked outside county single women facing no reallocation in 2002

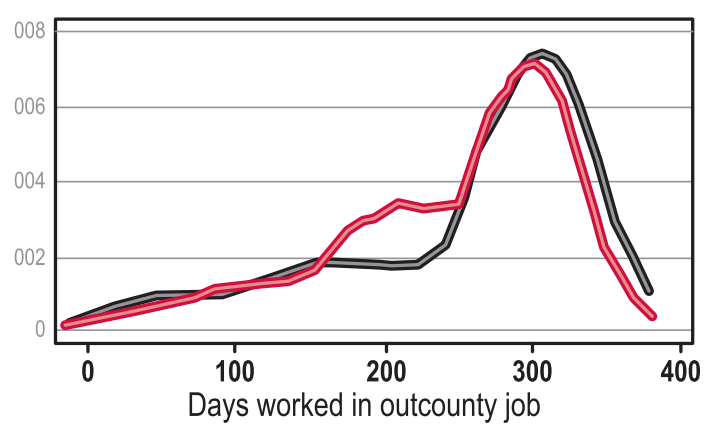

Days worked outside county single women facing a reallocation

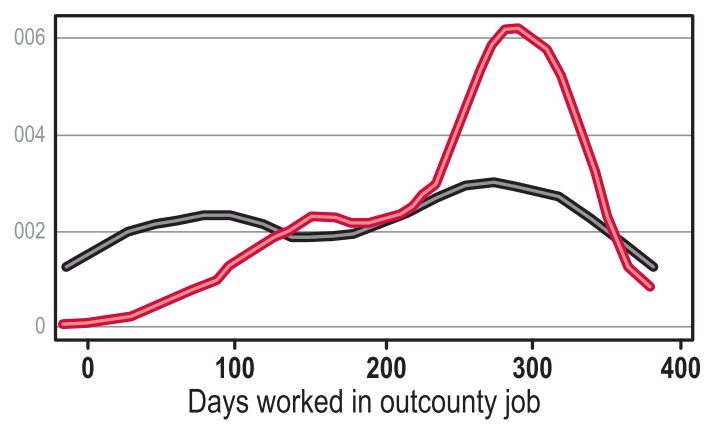

No grain ration land $\Longrightarrow$ Some grain ration land

Source: Authors' computation from CHIP, CASS, 2002

China, although it was not implemented everywhere. Twenty years later, this system is slowly disappearing, as grain ration land is granted with decreasing frequency to rural households. In 2002, however, this distinction was still relevant: more than 70 percent of the surveyed villages allocated some grain ration land in 2002. This allows us to define a plot-level dimension of land rights insecurity based on type of plot tenure. Since grain ration land is sometimes referred to as the rural "iron rice bowl," we can rely on its very existence to answer two sets of questions: Firstly, we have elements to determine whether land rights uncertainty influences migration $\mathrm{du}$ ration. The coexistence of two different tenure types provides a means of better capturing the risks taken by migrant workers who leave their land. Secondly, since grain ration land was designed for a specific task, it also sheds light on migrant people's insurance needs. If a temporary migrant faces a higher risk of loosing her responsibility land, then her land rights security should increase with the proportion of grain ra- tion land she can rely on. Similarly, the absence of grain ration land should be associated with shorter migration duration. The following graphs provide empirical results consistent with this analysis: the possession of kouliang tian is a critical factor in migrant behaviour. We present results for single women, since their greater vulnerability makes them the most sensitive to differences in tenure types.

The peaks correspond to the mode of migration durations in the survey data. For women who did not face a reallocation in 2002, the possession (red curve) or lack (black curve) of grain ration land does not greatly affect the pattern of migration duration. The observed gap even seems to indicate that women who possess some grain ration land migrate less in general. The second graph, however, exhibits a striking difference between the two curves; possession of grain ration land seems to be of crucial importance to women facing a reallocation. The black curve, representing the density of migration days for single women who have no grain ration land, is shifted to the left, and the peak at around 9 months is considerably lower. It appears, then, that single women react dramatically to a reallocation when their households do not possess any grain ration land.

We have seen that the three characteristics - village-level, plot-level, and individual level - modulating land rights insecurity are all associated with shorter migration durations. Reallocation encourages migrant workers to return earlier. This is especially the case for women. However, if these women possess some grain ration land, they can afford to migrate for longer periods, while those lacking any kouliang tian shorten the duration of their migration. Combined together, these three characteristics indicate how uncertainty in land use rights affects migrant workers' decisions.

\section{Conclusion}

Our work was founded on two main hypotheses: First, that land use rights insecurity acts as a constraint on the migration decisions of Chinese rural households due to the threat of collective authorities seizing the land of out-migrating individuals; and second, that this insecurity is idiosyncratic, and depends on village-level, plot-level, and household/individual-level characteristics. We can thus expect people facing a higher risk of losing their land use rights to migrate less, or for shorter periods.

32. Hanan G. Jacoby, Li Guo, and Scott Rozelle, "Hazards of Expropriation: Tenure Insecurity and Investment in Rural China," art. cit.

33. Dong Xiaoyuan, "Two-Tier Land tenure System and Sustained Economic Growth in Post1978 Rural China," World Development, vol. 24, n 5, 1996, pp. 915-928. 
Empirical observation confirms this analysis. When a land reallocation occurs, rural migrants cut short their out-migration in order to defend and assert their rights in their home village, as our data clearly show for the year 2002. But the exposure to this land seizure risk is modulated by the contractual status of land plots. "Grain ration land" (kouliang tian), in particular, is more secure than "responsibility land" (zeren tian). Indeed, the survey results indicate that people whose land includes a larger share of kouliang tian can afford to migrate more and longer when a reallocation occurs. Last but not least, different households and different individuals manifest different levels of informal power or social influence. Women's rights, especially, can be expected to be more easily challenged and jeopardised than men's. Indeed, the survey data indicate that women's outmigration decisions are more heavily constrained by villagelevel and plot-level insecurity than men's are. All in all, our hypotheses appear to be consistent with the survey data.

It is well established, theoretically as well as empirically, that collective ownership of agricultural land and the corresponding insecurity of individual rights constrains rural development. Indeed, the lack of long-term time perspective due to inadequate private rights prevents farmers from investing on their land, because the fruits of their investment could well be enjoyed by others. Hanan G. Jacoby, Li Guo, and Scott Rozelle, ${ }^{(32)}$ for example, have provided convincing evidence of a link between land rights insecurity and fertilizer use in the case of China. Moreover, as Dong Xiaoyuan points out, ${ }^{(3)}$ "Collective ownership makes land unsuitable as collateral for loans," and this clearly reduces Chinese farmers' access to formal credit. Generally speaking, the lack of private property rights and, consequently, of land markets, can be seen as a hindrance to efficient allocation and use of land. One further item has recently been added to this list of potential drawbacks to land collective ownership, namely the constraint on rural people's movement caused by land rights insecurity. In the case of China, the aforementioned works by Dennis Tao Yang, ${ }^{(34)}$ Bryan Lohmar, ${ }^{(35)}$ and Shi Xiaoxia ${ }^{(36)}$ have already focused on this issue, and our present study confirms their results.

Collective land ownership thus appears to complement the hukou household registration system in the Chinese framework of population movement control. Indeed, the rural/urban divide embedded in the hukou prevents most rural people from definitively settling in cities and keeps them in a marginal and disadvantaged position in urban centres. The hukou institution thus acts as a back-pushing force on rural-urban migrants, while collective ownership of land and the correlative insecurity of individual land use rights act as a back-pulling force on these migrants.
On first sight, Chinese rural institutions thus appear to form an effective barrier to land exchanges and labour movements, and therefore to the efficient allocation of these production factors. Moreover, as land rights insecurity is idiosyncratic and especially affects rural individuals with little informal power or social influence, the cumulative constraint on migration is more acute for people with fewer opportunities in rural areas. For example, women's land use rights are less secure than men's, as a result of which their out-migration opportunities are constrained by higher risks and costs, and this exacerbates their secondary social status, as men have more chances to acquire financial means and social recognition through successful out-migration to urban centres. All these analyses ultimately militate for a radical privatisation of land rights in China on the grounds of efficiency as well as equity. It turns out, however, that Chinese farmers do not generally seem to favour such an evolution, as James Kai-sing Kung and Liu Shouying ${ }^{(37)}$ were the first to notice during their inquiry into Chinese farmers' preferences. It is thus possible that all these drawbacks of collective land ownership are seen, in Chinese rural areas, as the price to pay for as yet under-studied benefits of this institutional framework. For example, even if land use rights on individual plots are not guaranteed through time, the collective management of land ensures access to agricultural land for any rural individual. It could thus constitute an insurance device for Chinese rural residents, who, generally speaking, are sorely lacking in all kinds of social security services. Our study results seem to support this intuition, with reliance on the land indicated by the huge proportion of people who tend to shorten their stay in cities when a reallocation occurs. Even if the land is in itself insufficient to support a household's living, and even if members of a farming household aspire to off-farm occupations nearby or in distant cities, the land remains a form of protection when the future is uncertain.

$\begin{array}{llll}\text { Glossary } & & & \\ \text { liudong renkou } & \text { 流動人口 } & \text { zeren tian } & \text { 責任田 } \\ \text { hukou } & \text { 户口 } & \text { kaihuang di } & \text { 開荒地 } \\ \text { ziliu di } & \text { 自留地 } & \text { tiliu jidong tian } & \text { 提留機動田 } \\ \text { kouliang tian } & \text { 口糧田 } & \text { tiaozheng } & \text { 調整 } \\ \text { chengbao tian } & \text { 承包田 } & \text { cunmin daibiao } & \text { 村民代表 }\end{array}$

34. Dennis Tao Yang, "China's Land Arrangements and Rural Labour Mobility," art. cit.

35. Bryan Lohmar, "Land Tenure Insecurity and Labour Allocation in Rural China," art. cit.

36. Shi Xiaoxia, "The Impact of Insecure Land Use Rights on Labour Migration: The Case of China," art. cit.

37. James Kai-sing Kung, "Equal Entitlement Versus Tenure Security under a Regime of Collective Property: Peasant's Preference for Institutions in Post-reform Chinese Agriculture," Journal of Comparative EconomicsThe China Journal 